\title{
DO TALENTO DE ALDYR GARCIA SCHLEE NASCERAM O FARDAMENTO CANARINHO DA SELEÇÃO BRASILEIRA DE FUTEBOL E MUITOS GOLS NAS PÁGINAS ESPORTIVAS DO RS
}

\author{
DEL TALENTO DE ALDYR GARCIA SCHLEE NASCERAM O FARDAMENTO CANARIÑO \\ BRASILEÑO DE LA SELECCIÓN BRASILENA DE FÚTBOL Y MUCHOS GOLES EN LAS \\ PÁGINAS DEPORTIVAS DE RIO GRANDE DEL SUR
}

Marli Hatje

Professora da Universidade Federal de Santa Maria

\section{Resumo}

A entrevista que compõe este texto é uma importante contribuição à história brasileira, sobretudo à história da Seleção Brasileira de Futebol e do jornalismo esportivo do Rio Grande do Sul/Brasil. Aldyr Garcia Schlee, cronista esportivo, criador do fardamento canarinho em 1953/1954, e que também ilustrava páginas esportivas em jornais do RS, principalmente, com gols de partidas de futebol, concedeu esta entrevista em 1995 sobre sua trajetória no jornalismo esportivo.

Palavras-chave: Seleção Brasileira de Futebol. Jornalismo esportivo. Ilustrações esportivas

\section{Resumen}

La entrevista que compone ese texto es una importante contribución a la historia de Brasil, especialmente a la historia de la selección brasileña de fútbol y del periodismo deportivo de Río Grande del Sul / Brasil. Aldyr Garcia Schlee, periodista deportivo, creador del uniforme "canarinho" en 1953/1954, y que además ilustraba las páginas deportivas en periódicos del Estado, principalmente con imágenes de los goles de los partidos de fútbol, concedió la entrevista en 1995 sobre su carrera en el periodismo deportivo.

Palabras clave: Equipo de fútbol de Brasil. Periodismo desportivo. Ilustraciones deportivas

\section{CONSIDERAÇÕES INICIAIS}

Esta entrevista, inédita, faz parte da minha história profissional e da história da imprensa (esportiva) do Rio Grande do Sul. Foi concedida à autora em 26 de agosto de 1995 na rua Butuí, 193 A, em Pelotas, RS, onde residia Aldyr Garcia Schlee ${ }^{1}$, o criador do fardamento canarinho da seleção brasileira de futebol, desenhista de gols do futebol e de

\footnotetext{
${ }^{1}$ Prestes a completar 81 anos, em outubro de 2015, o prof. Aldyr Garcia Schlee, residente em Pelotas, leu e revisou novamente o texto resultante da entrevista concedida em 1995 e autorizou sua publicação na presente versão. As imagens e fotos são do acervo particular de Aldyr, gentilmente, cedidos para este texto.
} 
caricaturas políticas. Trechos da entrevista integram a dissertação, intitulada $O$ jornalismo esportivo impresso do Rio Grande do Sul de 1945 a 1995: a história contada por alguns de seus protagonistas, defendida no Programa de Pós-Graduação em Ciência do Movimento Humano, do Centro de Educação Física e Desportos da Universidade Federal de Santa Maria em maio de 1996.

Aldyr foi um dos 22 profissionais da imprensa (esportiva) impressa do Rio Grande do Sul entrevistados para a dissertação. As falas dos protagonistas, em 1994 e 1995, foram gravadas e seguiram um roteiro pré-estabelecido com seis questões: $1^{\text {a }}$ ) História de vida antes e depois do ingresso no jornalismo esportivo impresso (JEI); $2^{\mathrm{a}}$ ) Participação na editoria esportiva; $3^{\mathrm{a}}$ ) considerações sobre as características do JEI; $4^{\mathrm{a}}$ ) As contribuições do JEI; $5^{\mathrm{a}}$ ) Os profissionais do JEI; $6^{\text {a }}$ ) Cobertura do JEI. Todas as entrevistas foram gravadas.

A pesquisa que envolveu os entrevistados caracterizou-se como histórica e teve como base a realização de entrevistas para a criação de uma documentação histórica. As técnicas utilizadas foram a de histórias de vida, através da técnica de história oral, e de pesquisas bibliográficas e biográficas.

Como a técnica da história oral dispensa um questionário previamente elaborado, bem como a possibilidade de respostas previstas, mas considera fundamental a vivência pessoal de cada indivíduo, a estrutura deste texto não segue na íntegra as questões definidas no roteiro e tampouco a ordem pré-estabelecida. Durante sua fala, o entrevistado vai e vem de acordo com a importância dos fatos em diferentes períodos e contextos de sua vida. As perguntas serviram apenas para que o entrevistado pudesse orientar sua memória no sentido em que detém mais informações. O roteiro, portanto, serviu apenas para ajudar a manter a fluência da entrevista, evitando a perda de informações importantes.

\section{ASPECTOS DE SUA HISTÓRIA DE VIDA}




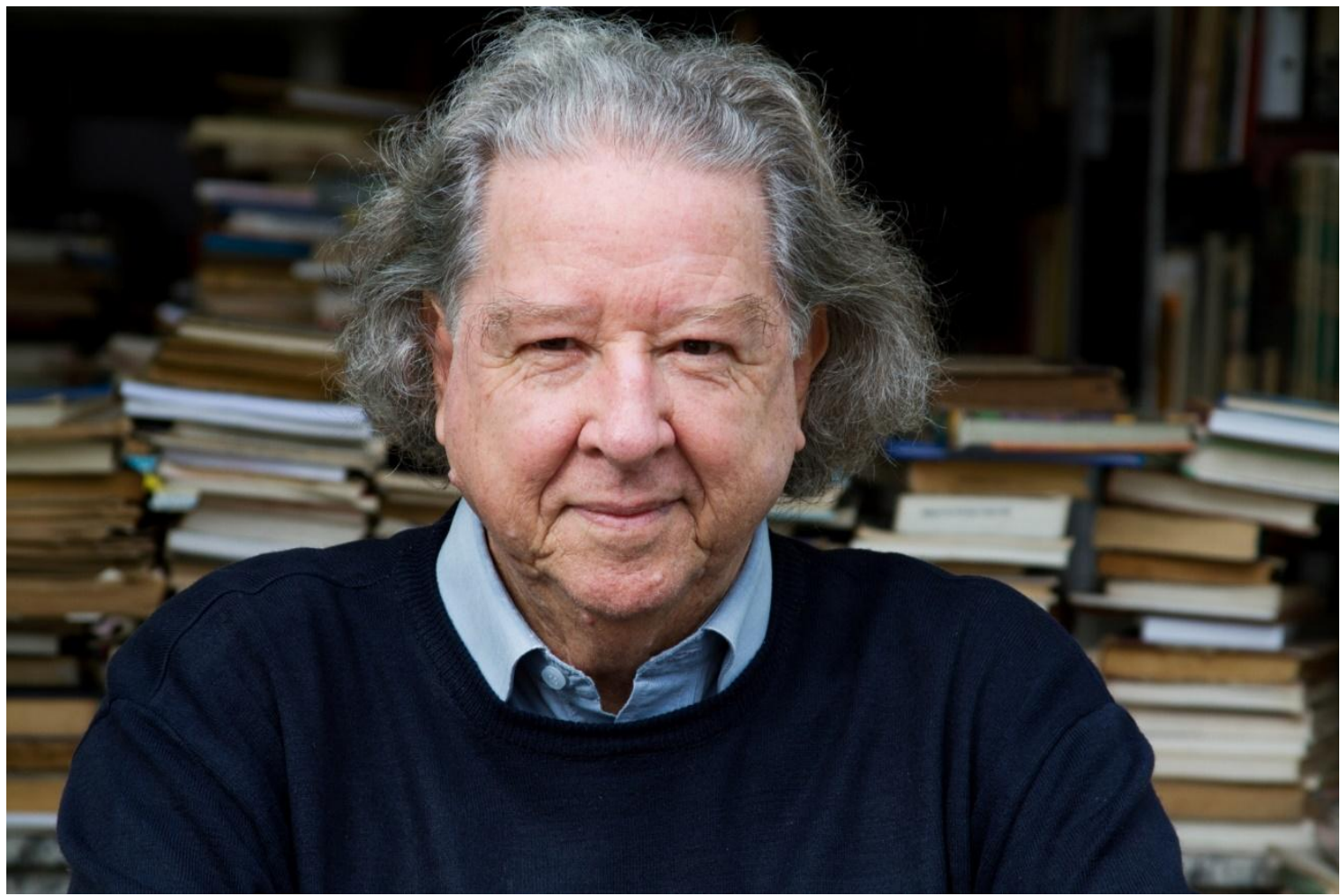

Figura 1 - Aldyr Garcia Schlee aos 81 anos de idade.

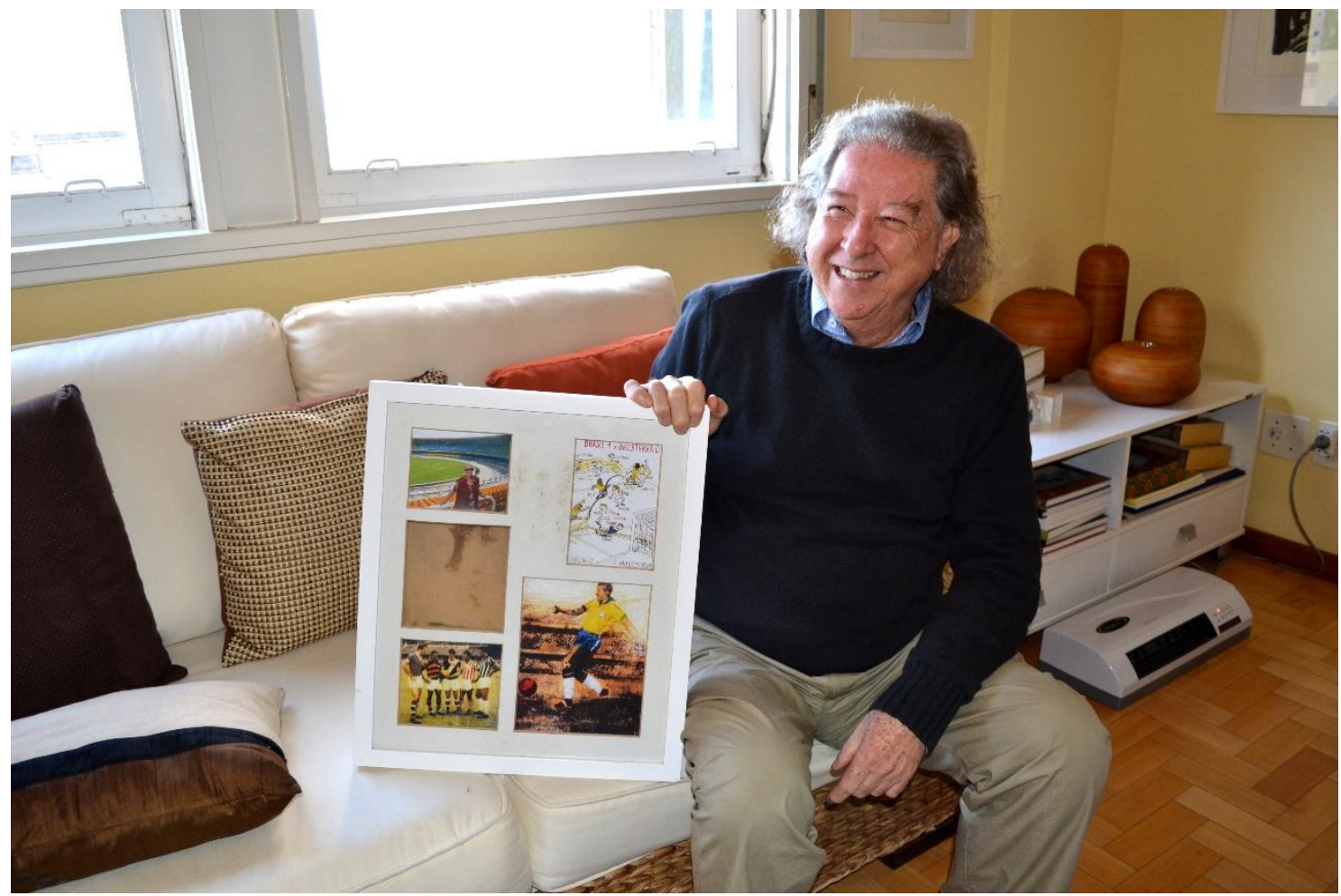

Figura 2 - Aldyr com fotos e ilustrações que marcaram a história do jornalismo no RS.

Aldyr Garcia Schlee nasceu em Jaguarão, na fronteira com o Uruguai, em novembro de 1934. É casado com Marlene Rosenthal Schlee e tem três filhos: Aldyr, Andrey e Sylvia. Graduado em Ciências Jurídicas e Sociais, é doutor em Ciências Humanas, escritor e 
professor. Foi docente e Pró-Reitor na Universidade Federal de Pelotas, mas também um dos fundadores do Curso de Jornalismo da Universidade Católica de Pelotas. É autor de 19 obras em português e espanhol, além de 17 antologias (listados ao final do texto). Trabalhou na área do jornalismo de 1950 até 1965, retornando ao setor, como superintendente editorial, em 1976.

Estudou no Instituto Porto Alegre, o IPA e residia com a vó. Semi-interno passava o dia na escola, com aula pela manhã, estudo orientado no início da tarde, depois esporte e à noite atividades culturais. O esporte tinha lugar especial e todos os alunos passavam por diferentes modalidades, como o futebol, vôlei e basquete. "Acabei praticando todos os esportes e aumentando ainda mais a minha paixão pelo futebol, pois eu tinha um tio goleiro em casa e me orgulhava disso".

Declarado torcedor do Cruzeiro de Jaguarão e do Cruzeiro de Porto Alegre. 'Tenho horror de Grêmio e Internacional", afirma enfaticamente.

Aos 15 anos já desenhava e quando mudou-se para Pelotas, começou a trabalhar como desenhista no Jornal da Tarde, onde fazia caricaturas políticas e ilustrações e no jornal A Opinião Pública onde desenhou os gols das partidas de futebol por cinco anos. "Eu era desenhista de futebol, uma coisa que hoje não existe mais, porque a televisão já liquidou com a necessidade dessa figura, que era o cara que ilustrava os gols das partidas".

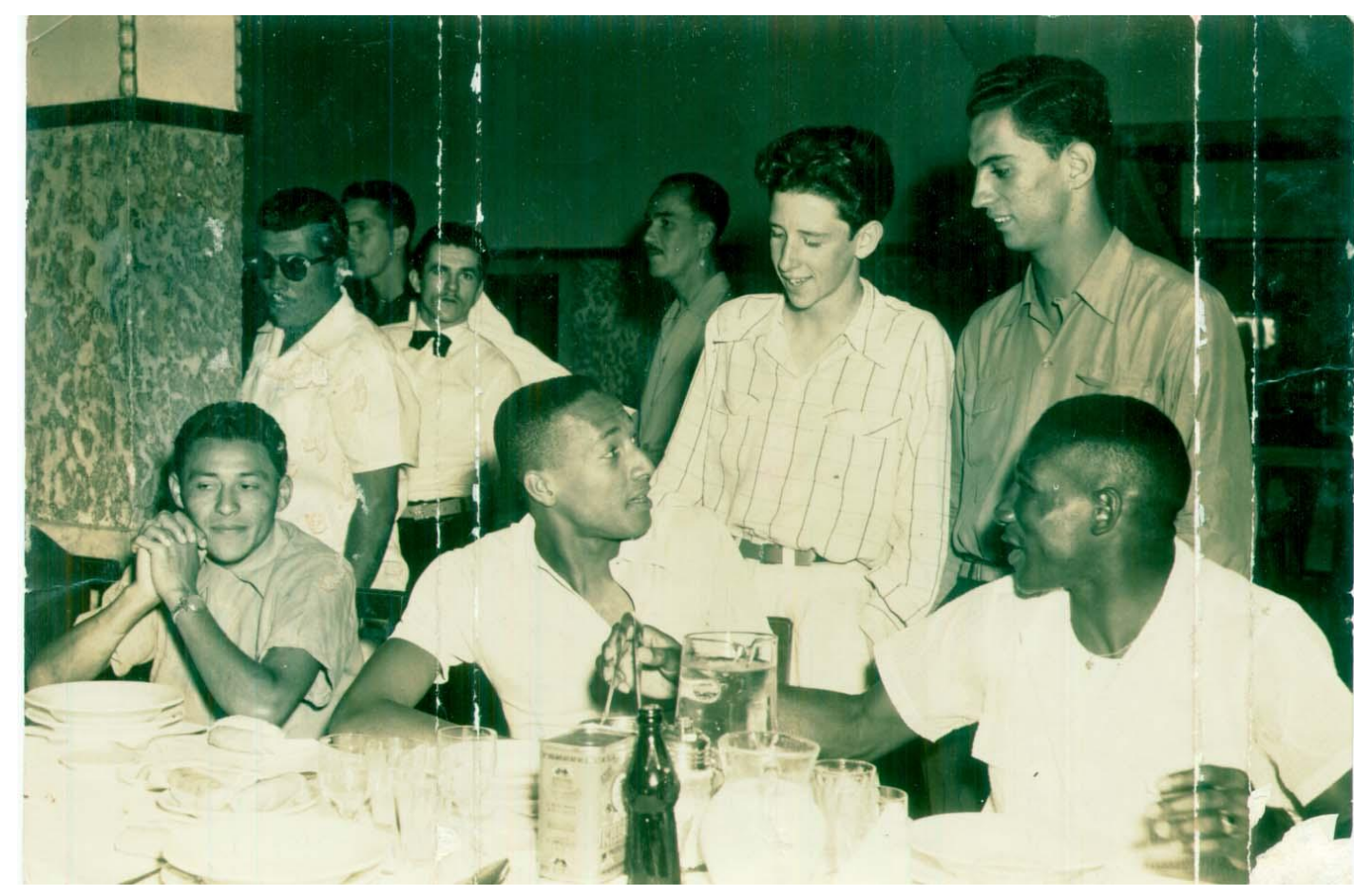

Figura 3 - Schlee em 1954 com Djalma Santos, Paulinho, Salvador e Dequinha, jogadores da Seleção Brasileira de Futebol. 


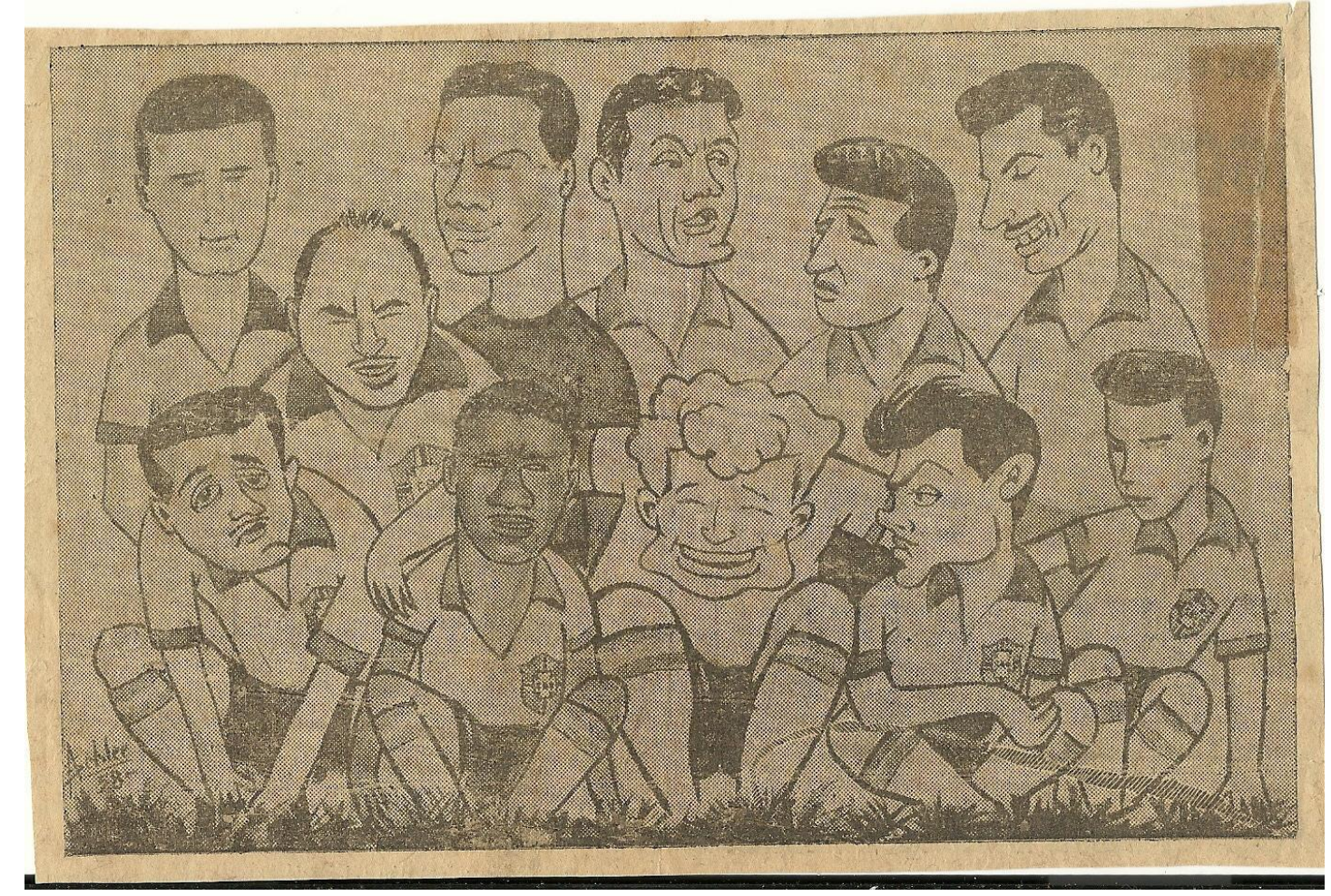

Figura 4 - Caricatura da Seleção Brasileira de Futebol (A Opinião Pública, junho 1958).

O esporte, principalmente, o futebol fez parte de sua vida desde criança quando já desenhava e lia sobre futebol. Era assinante das revistas semanais Mundo Deportivo (de Montevidéu), El Gráfico (de Buenos Aires) e O Esporte Ilustrado (do Rio de Janeiro). "Esta revista existiu do final da década de 30, desde o campeonato mundial de 38, até os anos 50, e era dirigido por Levi Kliemann.” Era no O Esporte Ilustrado e no El Gráfico que observava os gols desenhados. O jornal argentino fazia sequências fotográficas dos gols, mas muitos eram ilustrados. Com isso "comecei a desenvolver a técnica de ilustrar gols e com esse trabalho consegui emprego em A Opinião Pública, de Pelotas, como desenhista de gols".

$\mathrm{Na}$ época, tímido e com 15 anos, não gostava de acompanhar os colegas do jornal na cabine de imprensa. "Eu gostava mesmo era de ficar na arquibancada porque tinha medo daqueles caras, que bebiam e era uma coisa assustadora para um menino de 15 anos; e tive que me violentar, vencer a timidez para fazer esse meu trabalho de desenhar gols". Aldyr desenhou gols até os 19 anos, sempre com muito entusiasmo.

Em 1954 venceu um concurso nacional, patrocinado pela Confederação Brasileira de Desportos (então CBD, hoje CBF) para a escolha de um novo uniforme para a seleção brasileira (até então branco e azul). Desde então -e até hoje - o uniforme da seleção passou a ser o correspondente ao seu desenho: camiseta amarela, com punhos e gola verde, calção azul e meias brancas. No Rio, desfrutando de parte do prêmio que recebeu pela vitória sobre mais 
de duzentos candidatos, no concurso, fez estágio no jornal Correio da Manhã e acompanhou as atividades do diagramador paraguaio Andrés Guevara, considerado "o melhor da América Latina”. Nesse período passou a ter maior visão do jornalismo gráfico, área em que atuava, e ao mesmo tempo começou a perceber que as novas técnicas envolvendo a fotografia iriam liquidar definitivamente com sua função de desenhista de gols de partidas.

Mas, ainda nos jogos das eliminatórias da Copa do Mundo de 1954, desenhou os gols dos jogos Brasil x Paraguai e Brasil x Chile para vários jornais. Depois, quando virou cronista esportivo e secretário de redação, continuou escrevendo a crônica esportiva dominical, com ilustrações e desenhando gols de partidas de futebol.

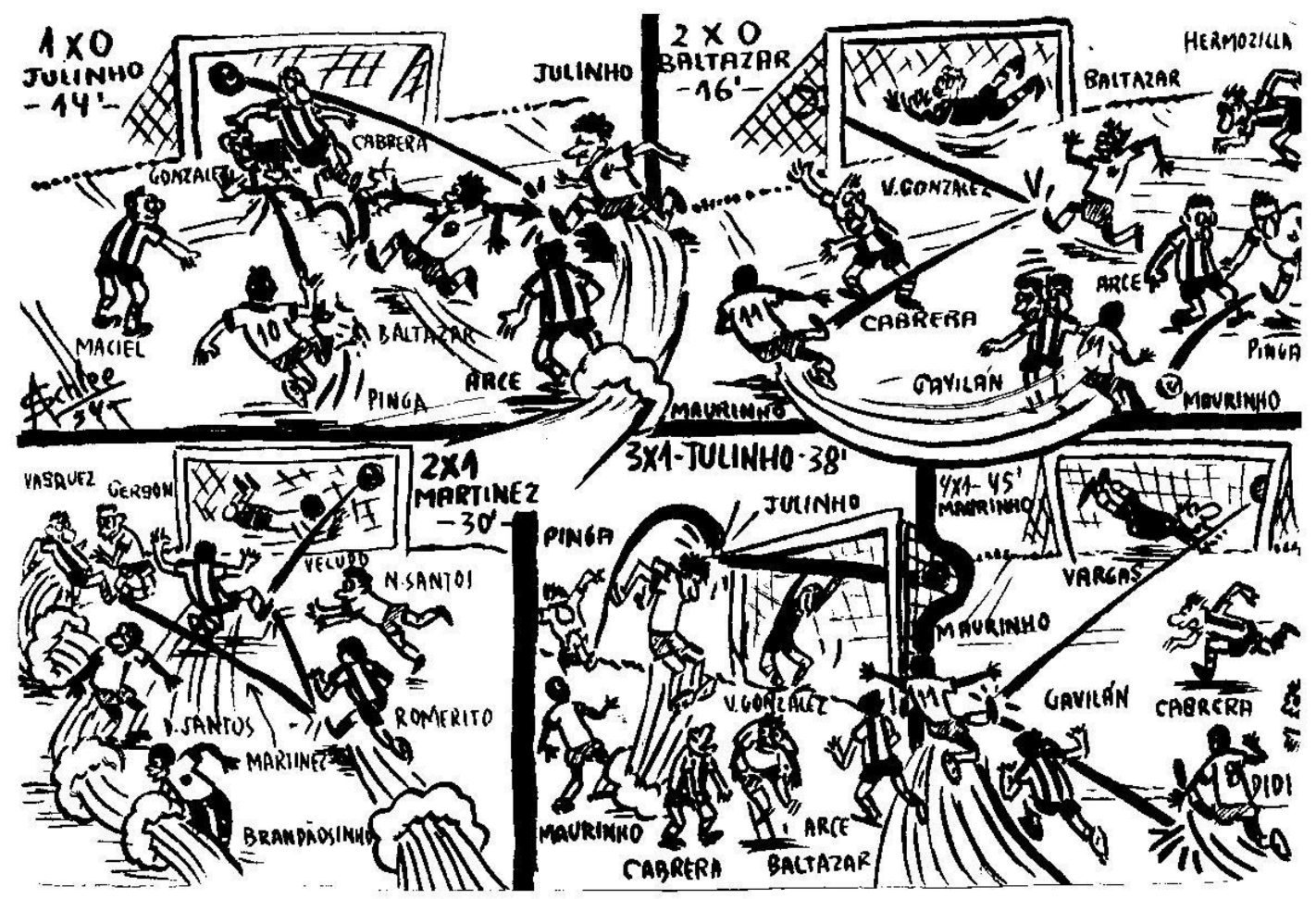

Figura 5 - Gols da partida Brasil 4 e Paraguai 1, em 1954. 


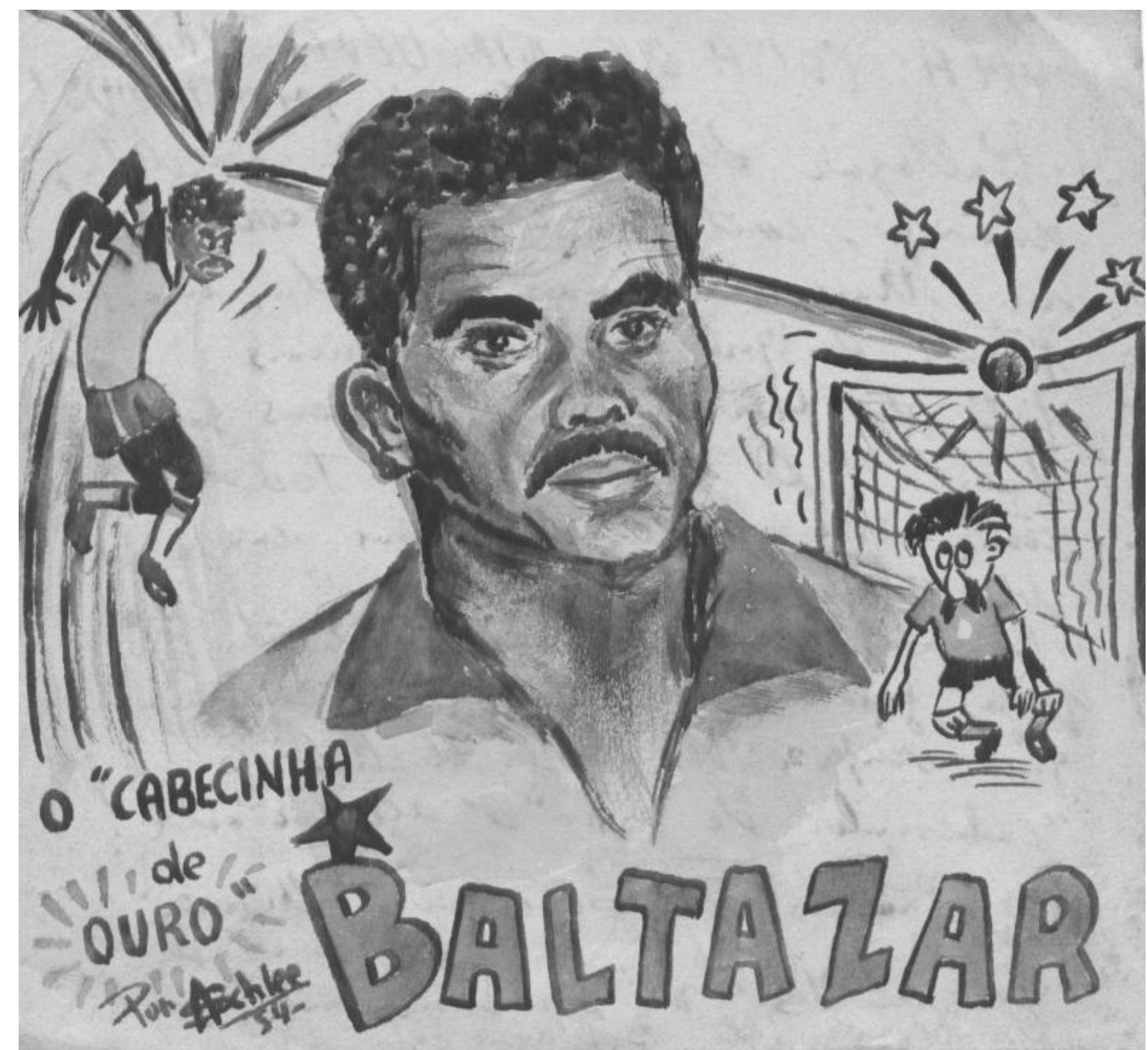

Figura 6 - O gol de Baltazar na vitória de 1x0 sobre o Chile, em 1954.

Com o passar do tempo, o período em que Aldyr se dedicava exclusivamente à função de cronista esportivo vai se esgotando. Em Pelotas, ele dirige o vespertino A Opinião Pública, onde escreve duas a três crônicas por semana; e edita, no matutino Diário Popular, uma longa coluna diária chamada "Em dia com o Diário" e outra semanal, "Diário de 7 dias". Ao se mudar para Porto Alegre, em 1959, como planejador gráfico e fundador do jornal Última Hora, de Samuel Weiner, já ajudara a fundar o Curso de Jornalismo da Universidade Católica de Pelotas.

Sobre a fundação desse curso, diz que se arrependeu: "se cometi algum erro fui fundar o curso de jornalismo na Universidade Católica de Pelotas, pois foi muito prematuro. Penso, aliás, que a formação universitária é muito importante para o jornalista, mas não deve ser uma exigência em termos de regulamentação profissional para todo e qualquer jornalista. É muito importante, sim, a formação acadêmica; entretanto, quando nós criamos o curso, não havia demanda em Pelotas, não havia o que o justificasse.” 
$\mathrm{Na}$ época em que foi criado o curso no Sul do Estado, estavam surgindo também muitos outros pelo Brasil. A favor da formação universitária, mas crítico da regulamentação profissional que considera uma medida autoritária, Schlee exemplifica a questão com sua função de escritor: "se um dia se exigir que cada escritor tenha que ter o curso de letras, por exemplo, eu não poderei ser mais escritor. É o tipo de coisa absurda".

\section{Marli - O senhor foi o vencedor do concurso que escolheu o novo fardamento da seleção brasileira de futebol em 1954. Dá para falar sobre como surgiu a idéia do “fardamento canarinho"? Que consequências trouxe ao futebol brasileiro?}

Aldyr - A ideia surgiu de uma norma regulamentar do concurso, que exigia a utilização das quatro cores da bandeira nacional - o verde, o amarelo, o azul e o branco - na elaboração do desenho do novo uniforme da seleção brasileira. Cem, dos trezentos desenhos de artistas que concorrerem a esse concurso foram descartados antecipadamente por não corresponderem às exigências regulamentares; e, certamente, muitos por não usarem todas as quatro cores previstas.

$\mathrm{Eu}$, inicialmente, julguei um absurdo, a exigência. Mas, quando me dei conta de que não se tratava de botar quatros cores numa camiseta, mas de arranjá-las adequada e equilibradamente entre camisa, calção e meias. Era criar e desenhar, com capricho, o melhor arranjo possível. 


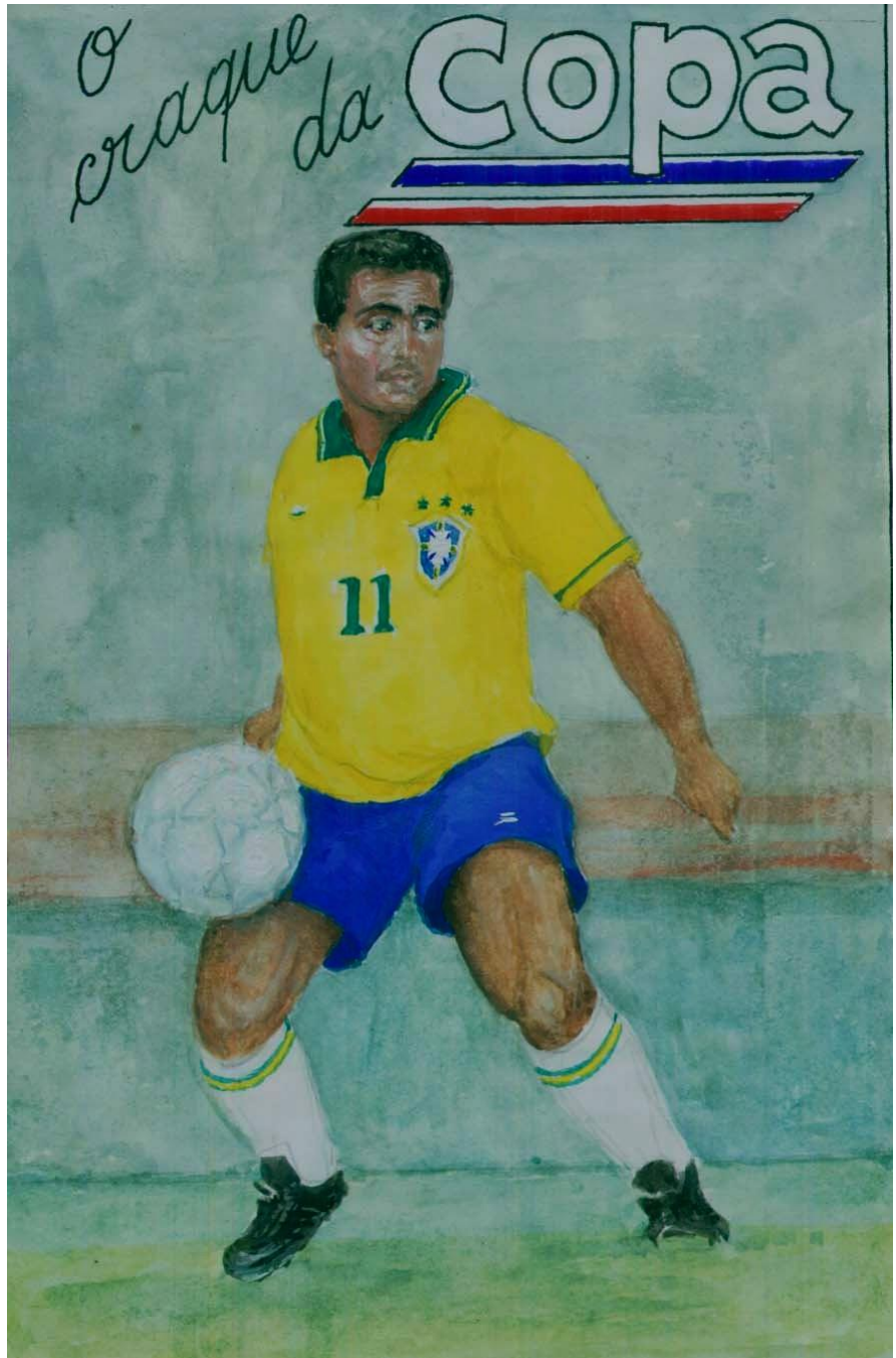

Figura 7 - Jogador Romário na Copa de 1994 com o fardamento canarinho criado por Schlee

\section{Marli - Quem era o cronista esportivo que atuava no jornalismo impresso?}

Aldyr - O cronista esportivo era uma figura bem definida, era o sujeito que descrevia o jogo como um todo, fazia uma crônica realmente a respeito do desenvolvimento de uma partida de futebol. "Havia os detalhes objetivos que ficavam numa ficha técnica, e o resto era algo que não chegava a ser ficcional, mas alguma coisa que era elaborada, que tinha gosto de Belle Époque, cheio de adjetivação. Hoje não se descreve mais o jogo.”

Quando escrevia a crônica dominical dos jogos de Pelotas, busquei introduzir na imprensa local novidades que não eram tão novas assim, porque no Rio de Janeiro já se praticava. Buscava transformar o texto da cobertura de um jogo em algo no qual o leitor pudesse encontrar em espaços diferenciados graficamente, informações variadas, o que hoje todo mundo faz e era uma novidade fantástica, na época.

A partir de então era feita a diagramação e estabelecidas diferentes funções entre aqueles que iam a campo. Com isso "acabamos fazendo loucuras aqui em Pelotas, publicando, 
por exemplo, uma edição do jornal A Opinião Pública num domingo, que circulou minutos depois do jogo Farroupilha x Grêmio, com a reportagem completa da partida".

O fotógrafo ia aos jogos, fazia fotos no início e ao final do primeiro tempo voltava para a redação para revelar e preparar a ilustração principal. Na redação havia um arquivo fotográfico com o "retratinho" de todos os jogadores, e assim que começava o jogo, o pessoal que ficava na retaguarda organizava as equipes que tinham começado a partida, separando os jogadores, e ao lado de cada um havia um espaço para colocar o julgamento de sua atuação. "Ficava bonito, e isso nós fizemos algumas vezes em A Opinião Pública e nos deu grande satisfação pessoal porque era algo que estava ao nível do jornalismo do Rio de Janeiro e São Paulo, mas que só se fazia em Buenos Aires".

Marli - Como surgiu a editoria de esporte nos jornais? Ela continua tendo a mesma importância?

Aldyr - A editoria de esportes cresceu muito nos jornais, mas hoje está perdendo espaço. Nós tivemos na imprensa do RS um momento importantíssimo que foi um pouco anterior à criação da Última Hora, em Porto Alegre. O apogeu do jornalismo esportivo no Estado culminou com a fundação, por parte da Caldas Júnior, proprietária dos jornais Correio do Povo e Folha da Tarde, do jornal Folha da Tarde Esportiva, matutino exclusivamente esportivo. Esse foi o grande momento do jornalismo esportivo do RS, pois surgiu uma publicação esportiva de excelência, que marca o ápice do desenvolvimento da informação esportiva e da necessidade que tinha o público daquele tipo de informação e daquele tipo de jornalismo.

Entretanto, a qualidade não era boa. Se observarmos a coleção da Folha da Tarde Esportiva, percebemos que o tipo de jornalismo praticado era decadente, era um jornalismo que tanto do ponto de vista do texto, como do ponto de vista gráfico, estava atrasado. O texto, por exemplo, era de um toque romântico que já não se utilizava mais nos jornais da própria Caldas Júnior, exceto o Correio do Povo.

O jornal Última Hora criado por Samuel Weiner, surgiu com algumas inovações, principalmente em relação a um "jornalão" como o Correio do Povo, na época publicado em formato standard. Desde que surgiu a Última Hora, os sul-rio-grandenses - que já tinham a Folha da Tarde, começavam a revelar preferência pelo formato tabloide, talvez por influência da Argentina e do Uruguai, onde havia e há tabloides de muita importância, além dos jornalões. Com a Última Hora, veio a valorização profissional, com a formação de equipes qualificadas, mesclando pessoas daqui com outras do Rio de Janeiro e de São Paulo. 
As editorias esportivas contavam com o "velho" cronista, aquele que dava opinião sobre futebol. Ele escrevia diariamente sua opinião, e começou a ter notoriedade a partir dos anos 50. Até então a equipe não fazia essa distinção. O Cid Pinheiro Cabral, colorado declarado, que trabalhava na Folha da Tarde, desempenhava o papel de cronista, ao lado de outras pessoas que também escreviam.

Mas, na Última Hora, as coisas começam a ser bem definidas. A coluna esportiva passa a ser do cronista respectivo; e surge a figura do repórter (até então não se chamava o jornalista esportivo de repórter: eram todos cronistas esportivos, muitos vinculados à Associação Gaúcha dos Cronistas Esportivos). O repórter esportivo, essa figura é que vai buscar a informação. Depois, vão se deformando sua imagem e função. Bem depois, nos anos 60, o repórter esportivo vai se transformar em algo que eu acho tremendamente vicioso e triste com relação a sua própria condição de jornalista. E surge a figura do repórter entre aspas, isto é, o setorista - o que faz a cobertura facciosa de um clube específico.

\section{Marli - Dentro desse contexto, qual a importância do setorista esportivo? Ele} colabora com a qualidade do jornalismo?

Aldyr - O setorista é uma figura comprometida com o clube, e por aí passa então uma série de coisas que envolvem a corrupção no futebol, o "filhotismo", todos os defeitos que se possa imaginar no profissionalismo da imprensa. Eu acho que começa por aí o fim do modelo do jornalismo sério. O setorista é alguém que está comprometido, antes de mais nada, com a verdade do clube, com a verdade dos meandros, dos bastidores do clube, e daí que a informação passa a ser desinformação e essa desinformação não interessa a ninguém, naturalmente.

\section{Marli - E qual o papel da publicidade no jornalismo esportivo?}

Aldyr - Bom, essa é outra questão séria, a questão do papel da publicidade. Tem a ver com as empresas jornalísticas de nosso país, com chamada mídia e com o desenvolvimento tecnológico dos meios de comunicação. Pode ser resumida no seguinte: nós importamos um modelo primeiro mundista para a administração das nossas empresas pretensamente jornalísticas e predominantemente publicitárias; e, no entanto, essas empresas raramente correspondem ao padrão importado, de modo que o jornal, o rádio, a televisão que nós temos são pobres, insatisfatórios, quase sempre irrelevantes culturalmente, limitados às prioridades estabelecidas pela própria publicidade. A partir da formação e do atendimento da vontade e do gosto de um público consumidor cada vez mais dócil e menos exigente.

Daí que houve uma inversão de valores dentro da imprensa brasileira, isso em todos os grandes jornais, começando pelos do Rio e São Paulo. Mas, pior é o monopólio da informação 
que nós temos no Rio Grande do Sul, através da Zero Hora, da RBS. Todos os jornais têm um padrão administrativo imposto de primeiro mundo que transformou e que inverteu os valores e em vez de valorizar realmente o profissional que é acima de tudo comprometido com a verdade, com um texto, com a qualidade do jornal; esse padrão valoriza a figura de quem é promovível, que possa se transformar num elemento a trazer ganho publicitário ou ganho institucional para o jornal.

E isso se faz em nome da liberdade de imprensa - assegurada aos jornais e aos donos de jornal. E negada àquele sem o qual não haveria jornal, o que faz o jornal, o empregado de jornal - o jornalista - sempre que sua opinião ou postura não corresponda à linha da empresa que vive dele e o trata como se fora um escravo do jornalismo.

Por outro lado, se o pobre profissional de imprensa se vende e vende espaço no jornal, no rádio, na TV, vai vencendo e queimando etapas, vai tendo estímulos financeiros para isso. Então, baixa-se o padrão do vencimento profissional ao mínimo e o cara tem que se virar para conseguir merchandising ou qualquer coisa que seja como se faz até com os atores da Rede Globo. E esse é um modelo de administração primeiro mundista que liquida com a seriedade e com a dignidade profissional.

E isso atinge o esporte, particularmente, porque no esporte temos hoje uma profissionalização que não se limitou ao pagamento do atleta em retribuição ao trabalho que ele faz, mas que chegou até à camisa do clube, que está vendida. É a venda das camisetas, a venda dos homens e das ilusões. E neste momento a gente passa a acreditar menos no futebol.

Acho que coisas desse gênero não dignificam o futebol. E o esporte só tem perdido com isso. O esporte, no Brasil, ou é o futebol ou é um episódio acidental, como foi o tênis de Guga, era o vôlei e terá sido o basquete, ou é algo explorado grotescamente pela publicidade como os referentes ao Fittipaldi, ao Piquet e ao Sena.

\section{Marli - Qual o papel social e histórico do jornalismo esportivo?}

Aldyr - Nós precisaríamos, por exemplo, repensar o papel social e histórico do jornalismo. Nós estamos deixando passar, por exemplo, toda uma fase fundamental do nosso futebol (vamos ficar apenas no futebol) e na qual ganhamos cinco campeonatos mundiais sem que a nossa imprensa fosse usada, realmente, como testemunha disso, porque nossa imprensa tem ficado na superficialidade primeiro mundista e não tem dado conta do seu compromisso histórico de registrar as coisas para que no futuro elas possam ser verificadas.

Nós não tivemos nesse período que inclui a realização da Copa do Mundo no Brasil, por exemplo, a publicação de revistas esportivas, porque a Placar morreu - e só renasceu para outras finalidades. Mais: nossos jornais não dão os resultados das partidas com a respectiva 
ficha técnica, com os times que jogaram, com os gols, a não ser raramente, a não ser que o horário de fechamento permita. É só pegar a coleção da Zero Hora, por exemplo, e perceber o seguinte: com o fechamento prematuro, cada vez o jornal informa menos e sonega mais informações fundamentais.

O fato de a gente sair no sábado e já encontrar o jornal de domingo à venda é coisa de chorar. Mas, agora eu imagino o seguinte: se o acontecimento esportivo ocorreu na terça-feira à noite e na quarta e quinta-feira o jornal não dá, nunca mais vai dar. A Folha de São Paulo está tentando acertar isso, publicando os resultados de anteontem num quadrinho. Mas, de qualquer maneira, vejo que há uma distância enorme entre o que se está oferecendo e aquilo que corresponderia às necessidades de oferecimento, independente de uma demanda específica, mas sim pela função do jornal como testemunha de seu tempo.

\section{Marli - E os jornais do interior dão conta disso?}

Aldyr - Os nossos jornais do interior hoje pioraram muito em relação a isso. Eu acho que é um fenômeno nacional, a falta de consciência profissional daqueles que exercem o jornalismo. Nos grandes jornais, criou-se aquilo que se chama de efeito bumerangue, que é conhecido para quem trabalha com jornalismo. O jornalista das capitais faz apenas o jornal que ele lê; os jornalistas do interior fazem os seus jornais apenas, como os jornais das capitais, que leem; e, na medida em que esses jornais não têm um compromisso com a história, acabam sem dar informações objetivas que ocupem o mínimo de espaço - e que amanhã seriam necessárias para registrar um fato ocorrido como um testemunho.

Posso dar um exemplo: em Porto Alegre, temos na $1^{\text {a }}$. divisão do futebol do Rio Grande do Sul o Cruzeiro e o São José. Mas os jornais de Porto Alegre, dedicados exclusivamente à dupla Grenal, não fazem qualquer referências ao que acontece normalmente com São José e Cruzeiro, sonegando informações a cada semana e limitando-se apenas e, geralmente, ao registro do placar de seus jogos dominicais.

Então, acontece que os jornais do interior fazem como os grandes jornais das capitais e também sonegam informação. Nós temos, por exemplo, um time de Pelotas, o Farroupilha, disputando o campeonato de terceira divisão de profissionais. Quando se anuncia um jogo do Farroupilha e se dá a provável escalação, está se fazendo o máximo, aqui em Pelotas, que eu já encontrei a respeito do Farroupilha. No dia seguinte se diz, quando se diz, se o Farroupilha perdeu, ganhou ou empatou. Eventualmente se dá a escalação, mas não se dá a do adversário.

Isso parece bobagem ou coisa sem importância, no modelo de jornalismo - não só o esportivo - que fazemos no Brasil. Mas é algo grave e de relevante importância, para qualquer jornalista consciente de seu papel. Porque o que estou registrando tão singelamente, é uma 
barbaridade, um desserviço, um crime contra a memória do esporte, e cada jornal tem seu compromisso com essa memória. Mas, a culpa não é das pessoas, apesar de que o jornalismo esportivo no interior passou a ser hiper, super desvalorizado. Hoje, tudo decorre da própria decadência do futebol do interior e as razões que eu vejo para essa decadência estão ligadas à reformulação que aconteceu nos últimos tempos no futebol brasileiro, como a vinculação dos clubes aos patrocínios e, principalmente, à influência comprometedora e devastadora e a televisão.

\section{Marli - A televisão está assumindo esse papel histórico social?}

Aldyr - Nossa televisão tem um papel que ainda não foi bem definido, mas que já chega a nos assustar desde que propôs o afastamento do público dos estádios por causa das brigas de torcidas, ou o que seja, para que só seja visto pela televisão. Então, isso assusta porque constitui a própria negação do futebol e porque, na verdade, o extraordinário no futebol, como esporte, é o fato de que a gente pode ver o desenrolar de uma partida ao vivo, na certeza de que não terá replay; e isto é extraordinário e único porque o fascínio do futebol está em cada instante que passa e que não se repete, em cada novo momento de emoção, de temor, de alegria - e até de tristeza - que ocorre ali, no campo, do início ao fim de cada partida, num renovar-se permanente da repetida e continuada esperança de uma nova oportunidade, de uma nova possibilidade, de uma nova vitória, de um novo título.

Quanto à chamada "crônica esportiva", acredito que ela tem mais espaço nos jornais do que merecia. São quatro, cinco colunistas num só e mesmo jornal, falando as mesmas coisas sobre Grêmio e Internacional como se tratassem do futebol do Rio Grande do Sul.

Marli - Como eram tratados os esportes amadores na imprensa local e estadual? Para o jornalista há diferença?

Aldyr - Há uma palavra, uma expressão que no meu entendimento caracteriza bem esse tratamento. Eles são mal tratados e são colocados numa posição absolutamente desvantajosa. Há um maltrato duplo, nos dois sentidos, que a expressão possa significar. Há um tratamento errado, porque os jornalistas não têm o domínio que seria necessário ou a consciência da importância que tem o esporte amador para fazer uma bela, boa e necessária cobertura. Então, nesse aspecto o defeito é de consciência profissional. E tais esportes são mal tratados porque são colocados como coisa de segunda categoria, como coisa que serve para ser apresentada eventualmente como o exótico, o raro, desde o taekendô, ao aeromodelismo. Outro dia apresentaram na televisão o aeromodelismo de helicóptero (isso também é esporte, não é?). Então, qualquer esporte que não se transforme em atração para efeito de venda publicitária, especialmente na televisão, é um esporte secundário. 


\section{Marli - Quais são as características em relação a linguagem que se utiliza no esporte? Há diferenças para o amador e o profissional?}

Aldyr - Nós hoje temos que desenvolver uma linguagem objetiva, muito própria, muito adequada, que caracteriza o jornalismo impresso. No jornalismo da mídia eletrônica, a questão é discutível, seja no rádio, seja na televisão. E é tão discutível que basta a gente assistir e comparar a cobertura televisiva que se dá em nosso País para um evento de futebol, por exemplo. Eu fiz essa experiência, uma vez, no dia do jogo do Grêmio com o Nacional de Medellin. Em vez de ver o jogo pela TV brasileira eu vi pela TV colombiana. É outro modelo de cobertura, outro modelo de narração, é tudo completamente diferente. Tão parcial quanto a nossa, mas com um padrão bem mais excitante, bem mais interessante se comparado ao nosso. Agora, com relação aos textos jornalísticos de esportes, nota-se que eles estão enxutos e bastante objetivos. O texto esportivo é um texto fácil, e salvo as peculiaridades de um e outro jornal, está sendo uniformizado em todo País. Desde que o sujeito seja alfabetizado ele consegue produzir o seu texto com certa dignidade, dentro do nível de exigência que existe. $\mathrm{O}$ texto mais curto foi melhorando, e acho que nós ganhamos com isso, pois assim ocupa menos espaço e vale mais para o jornal pela objetividade.

O pente fino para retirar uma centena de adjetivos que se usava na década de 40, que começavam a ser questionados em 50, já chegou à imprensa do interior. Isso foi ótimo. Então, o texto do ponto de vista estritamente formal melhorou bastante. Com relação aos conteúdos, ele continua com os defeitos daquelas observações que eu fiz, e passa muitas vezes à desinformação, que é uma regra da imprensa brasileira e que tem consequências políticas no nosso país.

\section{Marli - É fácil ou difícil fazer jornalismo esportivo no interior? Por quê?}

Aldyr - A questão básica do jornalismo no interior é que todos conhecem todos. Todos são conhecidos. É preciso partir da certeza de que ninguém é isento, mas suficientemente profissional para procurar oferecer o máximo de isenção. Nós, aqui em Pelotas, utilizamos certa vez uma metodologia curiosa no jornal: reunimos três pessoas que trabalhavam com o esporte. Um ex-jogador e torcedor do Farroupilha (João Félix Soares Neto), um torcedor do Pelotas (Carlos Alberto Chiarelli, ex-senador e ex-Ministro da Educação) e eu, confessadamente torcedor do glorioso Grêmio Esportivo Brasil, e criamos uma coluna diária, onde cada qual utilizava um pseudônimo. Na coluna mantínhamos um debate escrito defendendo cada um dos nossos três clubes. E nós mesmos fazíamos jornalismo isento. Nos textos sobre jogos, sobre os problemas de transferência de jogadores, toda a informação esportiva que saía não era assinada. Os leitores sabiam que éramos nós que 
fazíamos, mas não identificavam as pessoas. E se criou a ilusão de que um de nós sempre estava submetido à censura dos outros dois. Era divertidíssimo fazer isso. E não havia leitor descontente ou desconfiado.

\section{Marli - Vocês sof riam algum tipo de censura no interior do estado?}

Aldyr - Não, mas sempre houve jogadores e dirigentes de clubes que nos ameaçavam. Essas coisas acontecem na província, na cidade pequena. Em Porto Alegre isso também aconteceu com dirigentes e jornalistas esportivos. No Rio de Janeiro e em São Paulo, porque o espaço é maior, não há tanta cobrança pessoal. Aqui no Estado, as coisas se tornavam meio folclóricas. O Paulo Santana, por exemplo, soube explorar muito bem a questão em Porto Alegre e se transformou numa figura folclórica, declaradamente gremista. Ele faz o que eu chamaria de jornalismo para-esportivo. Ele fala de futebol, mas ele não é um jornalista esportivo.

\section{Marli - Com que editoria o senhor compara o esporte?}

Aldyr - Bom, eu acho que o esporte tem uma peculiaridade muito própria. Mesmo numa cidade pequena não dá para se ter uma editoria mista na qual caiba o esporte, seja chamada de Local ou de Variedades. Essa expressão variedades é onde realmente se esconde a Cultura quando não se consegue ter uma atividade compatível com o respeito que a cultura merece - e onde pode até aparecer, ironicamente, a Polícia.

O esporte, em jornal, tem sempre um acontecimento previsível, um acontecimento com hora e data marcada, que tem que ser coberto. No futebol, o ponto culminante de uma cobertura é o acontecimento, o jogo. Fora do futebol em particular e dos esportes, em geral, o repórter não acompanha o fato, mas corre atrás dele. Veja uma questão em outra área, a mídia eletrônica: causou um impacto impressionante, inclusive, em termos de Ibope para a televisão brasileira um programa já esquecido: “Aqui e Agora”. O que ele criou? Criou a ilusão de que o repórter podia testemunhar o fato.

\section{Marli - E a linguagem?}

Aldyr - Bom, o nosso querido Nélson Rodrigues, o papa da crônica esportiva, o único grande cronista esportivo brasileiro, cronista de verdade, criou centenas de expressões lapidais. Todas elas muito exageradas, muitas delas hiperbólicas. Mas, eu acho que ele criou uma expressão que define bem essa distinção entre o futebol e tudo mais, em geral, e que não permite que o futebol caiba dentro de uma editoria. O esporte tem que ter uma editoria. Ele, a respeito do futebol, por exemplo, criou uma figura. Humanizou, deu um caráter humano para o imponderável. Então, é preciso observar o seguinte: nós, os que já fizemos crônica esportiva como o próprio Nélson, nós temos o privilégio de ser testemunhas do acontecimento que nós 
temos que cobrir e esperarmos o imponderável, ao passo que no resto de nossa atividade jornalística, o imponderável é que comanda as coisas e o repórter vem a cabresto dele. Ele não pode ser testemunha do acontecimento. Não há outra relação possível.

Agora, quanto ao texto, creio que se tornou óbvio e parecido. É claro que isso não significa boa lembrança da velha linha romântica, enfeitada, tosca, pobre, boba e cheia de adjetivação de antigamente. Mas, a obviedade atinge também a objetividade. E existem idiotas da objetividade nesse jornalismo brasileiro que não é brincadeira.

Marli - O que o senhor entende por esporte? Que contribuições ele trouxe à sociedade quando escrevias para o jornalismo esportivo?

Aldyr - Eu custei a compreender que esporte era uma coisa muito recente, e que fora criado para dar vigor físico às pessoas a fim de que elas respondessem com esse vigor físico, à indústria e ao trabalho. Era uma coisa típica da Revolução Industrial, posterior ao período em que a máquina começava a substituir o homem.

Esse conteúdo histórico e material do desenvolvimento da atividade física - que inclui não só o esporte, mas a ginástica, as atividades físicas coordenadas e orientadas, isso tudo eu não tinha percebido. Então, sobressaia para mim, como para todos e para a maioria até hoje, o aspecto mágico do esporte. Não só do esporte como tal, mas principalmente do esporte como competição, estimulando rivalidades e criando a expectativa boa de que a gente um dia vai ganhar.

Quando eu me dei conta disso - que o esporte era algo novo, que tinha sido inventado recentemente, com a finalidade de ocupar o tempo e desenvolver o físico de determinadas pessoas (para que as pessoas não incomodassem, para que não brigassem para que se organizassem e produzissem mais), eu comecei a perceber que havia outros aspectos fundamentais por trás disso tudo. E no momento que pude conviver com os jogadores, desde que estive com a seleção na Copa do Mundo de 1954, comecei a ver que o esporte profissional era uma forma de realização, especialmente para aqueles grupos que vêm das camadas inferiores da sociedade, que têm ali uma oportunidade única, na base apenas de sua habilidade. No caso do futebol com os pés, com a cabeça, mas é também uma profissão que tem que se dignificar. E nesse aspecto, os jogadores custam a compreender ou nunca compreendem a necessidade de dignificar a sua profissão, e se vendem.

Quando eu digo que se vendem, não quero dizer que se vendem para deixar de fazer um gol, pra deixar tomar um gol. Mas, o adjetivo fundamental do profissionalismo é que ele cria um falso espírito profissional no sentido de "eu sou um profissional". O sujeito que é um profissional, acima de tudo tem que se respeitar e se fazer respeitar. Mas, não! Se é um 
profissional, ele se vende, ele muda, na medida e na dimensão da proposta financeira que lhe fazem.

Eu não quero que seja retomado o espírito amador, não se trata de uma postura passadista, de uma postura nostálgica, de retrocesso. Não, não é isso. O espírito amador deve existir para dignificar o profissional, ou seja, fazer com que o profissional tenha que usar a camiseta como se aquela fosse a sua camisa do coração. Ele é pago para isso. E só aí é que ele vai provar que é bom. É nesse aspecto apenas que eu tomo o espírito amador. Mas, o que há é que o jogador recebe o dinheiro para trabalhar, mas ele recebe um dinheiro extra pra ganhar cada jogo, e aí se deteriora toda a questão profissional. Tudo se vai porque ele se vende. Ele ganha para trabalhar, depois vem o "bicho", que foi e tem sido ainda o grande mal do futebol brasileiro e de alguns outros países. Como entender que um jogador profissional tenha que ganhar dinheiro para ganhar - se ele está lá para ganhar? Isso é uma contradição que tem que ser vencida. E, além disso, o profissional ganha para expor na sua camiseta o nome de uma empresa, o patrocinador. Ele ganha pra vender a sua imagem na televisão. E todo esse conjunto de ganhos ainda não foi suficientemente deglutido por ele como profissional, que continua só querendo faturar, isto é, vender-se.

Marli - Na sua opinião, o jornalismo esportivo impresso influencia a sociedade ou as pessoas à prática da atividade física? Ele leva as pessoas à prática?

Aldyr - Não. O nosso jornalismo impresso não é suficientemente inteligente para compreender seu papel. Por isso, eu já o condenei dizendo que ele não tem consciência do seu papel histórico, de documento, de memória da comunidade. Então, nesse sentido, por falta de consciência desse papel por quem dirige o jornal, ele também deixa de dar essa resposta. Há um sofisma, uma balela de que o jornal, a televisão, em suma, aqueles que fazem o jornalismo esportivo, estimulam o esporte e a prática esportiva. Isso não acontece. A divulgação do esporte é feita para o jornal e não para o leitor. Isso é um grande defeito. Essa mão única é uma coisa triste: o jornal cada vez se promove mais. Ele se promove em cima do acontecimento. Ele diz que está promovendo o acontecimento, o que não é verdade. É ele se promove. E quando tenta promover o acontecimento, por exemplo, nos esportes amadores, revela-se todo o mau trato que o jornal dá ao esporte amador. As pessoas que, pretensamente, vão promover o esporte amador, não têm competência, elas não dominam aquele esporte e mostram seu total desconhecimento desse esporte.

Quando ocorrem jogos intermunicipais, só para dar um exemplo que eu conheço, imediatamente os órgãos de comunicação da cidade ou da região se transformam em divulgadores do evento. Na verdade, eles estão é aproveitando o evento para vender 
publicidade, conseguir um patrocinador, fazer um caderno especial. E aí se vê que há um desconhecimento total da maioria dos esportes que vão ser objeto daquele acontecimento. É uma pena!

Marli - Vocês tinham colegas mulheres na editoria de esporte aqui em Pelotas? E em Porto Alegre?

Aldyr - Não. Na Última Hora tivemos. Nós estávamos vivendo um momento da ascensão da mulher no jornalismo. Eu lembro que havia uma moça que frequentava a redação, que andava por lá e casou com nosso diagramador. E hoje ela é professora da Unisinos, mas na ocasião ela era "estagiária de calcanhar sujo". Havia um grande preconceito caracterizado pelo uso dessa expressão de Nelson Rodrigues. Mas, a partir de 60, as mulheres começam a ocupar o seu espaço. Eu quero a favor das mulheres dar um testemunho: acho que a presença da mulher no jornalismo em geral e, eventualmente, em algumas coberturas esportivas, ao contrário do que aconteceu em outras profissões como o magistério. Não aviltou a profissão. No magistério, a presença maciça das mulheres aviltou a profissão porque as entidades públicas como o Estado, por exemplo, encarregado de pagar a professora não se sentia comprometido a pagar um salário que fosse compatível com a necessidade de manter uma família. E, fazendo de conta que a mulher não tem que manter família, foi se aviltando o salário, e o magistério hoje está na situação que se encontra, apesar da legislação. E a culpa, evidentemente, não é da mulher. Mas, a presença maciça da mulher na profissão criou esse aviltamento porque ninguém se sentiu obrigado a pagar para mulher aquilo que teria que

pagar para o homem. É uma vergonha esse machismo sul-rio-grandense e brasileiro. Mas, no jornalismo não. Eu não sei porque as mulheres foram entrando devagar, foram ocupando seus espaços, chegaram às editorias, são excelentes jornalistas. Então não houve esse aviltamento profissional. É verdade que há um aviltamento geral: pagam pouco, mas isso é outra conversa.

Marli - Quando o senhor tinha dificuldade em fazer matéria sobre alguma modalidade esportiva, procurava alguma orientação? Quem?

Aldyr - Sim, isso aconteceu muitas vezes.

\section{Marli - Quem lhe ajudava?}

Aldyr - Não só aconteceu na condição de encarregado da cobertura, mas muitas vezes na condição de editor, de secretário de redação. Eu percebi isso sempre. Há até um conto meu que acabou sendo escrito por causa disto. Eu precisei fazer um trabalho com a Federação Gaúcha de Boxe para um campeonato gaúcho que iria se realizar em Pelotas, e eu não sabia nada sobre boxe. Então fui estudar boxe, fui saber tudo que precisava saber sobre boxe. E fiquei tão informado a respeito de detalhes técnicos do boxe que resolvi escrever um conto 
sobre isso. Tratei a questão técnica de tal forma que dá a impressão de que foi escrito por um expert, porque busquei revelar detalhes do boxe que o leitor comum, o espectador comum não conhece. Não só os nomes dos golpes, que são óbvios, mas a explicação para toda a técnica de treinamento. Hoje, uma das coisas que mais me constrange é saber que alguém vai fazer a cobertura de qualquer coisa, sem o mínimo de informação. Eu, por exemplo, gosto de jogar futebol-de-mesa, o velho jogo de botão. Não dá para chegar em um campeonato brasileiro de futebol-de-mesa e ver que alguém pergunta: "como é que se joga"? E as pessoas ficam fazendo charme disso. Outro dia eu vi na televisão uma menina fazendo reportagem sobre o jogo de botão, em um campeonato que houve no Rio de Janeiro. Fiquei entusiasmado: "Olha o futebol-e-mesa, vamos ver!”. Ela não sabia nada. Então toda a reportagem foi feita com base no que ela não sabia. Resultado: foi péssima a divulgação do esporte e ela ficou fazendo o papel de uma atriz, de uma tola que não sabia como é que se praticava aquele esporte e não informou nada. De modo que aquela reportagem não teve qualquer sentido ou razão de ser.

Marli - Em quem você se espelhava profissionalmente? Nelson Rodrigues lhe influenciou no jornalismo, especialmente, no esportivo?

Aldyr - Foi o Mário Filho, que escrevia uma página admirável na última página do Globo Esportivo. Mário Filho, irmão de Nélson Rodrigues.

Marli - Um jornalista consegue viver com o salário que recebe? É possível construir um patrimônio? É possível viver bem?

Aldyr - Não. Por isso que eu, por exemplo, tive que optar pela universidade. Eu deixei de ser jornalista porque não havia espaço para mim no jornalismo em 1965. Eu vi que não tinha mais condições de continuar trabalhando. Eu era professor da Universidade Católica, no curso de Jornalismo. Fui expulso da UC e as portas de todos os jornais se fecharam para mim. Somente em 1976 é que voltei a ser superintendente de um jornal. Uma experiência ótima, mas que durou pouco tempo. Durante todo o período da ditadura eu fiquei fora. Mas, a pergunta objetivamente é se o salário é compatível? Não, não é. Eu acho que o salário de um jornalista numa cidade grande deveria ser suficiente para ele sobreviver dignamente. Mas, o que se nota é uma distorção no modelo administrativo que veio do primeiro mundo. Então, há jornalistas muito bem pagos e há, no mesmo jornal aqueles que são extremamente explorados.

O melhor salário que eu já ganhei na vida foi em jornal. Eu, quando fui contratado pela Última Hora, ganhava o equivalente a 30 salários mínimos. E isso, na Universidade eu nunca ganhei, nem como Pró-Reitor. 


\section{Marli - Como é que vocês faziam a cobertura esportiva? Vocês iam para o exterior também?}

Aldyr - Não. A cobertura esportiva de jornal era garantida por uma norma, por uma regra, eu não tenho certeza se era lei federal, mas a norma era respeitada pelos clubes. Tenho a impressão que era uma norma do Conselho Nacional do Desporto (CND), que era rigidamente respeitada. Os clubes eram obrigados a respeitar. Qualquer excursão fosse ela para Capão do Leão ou para Rio Grande, de qualquer clube registrado na Confederação Brasileira de Desportos, através da Federação Gaúcha, tinha que levar obrigatoriamente jornalistas. Então, era fácil fazer coberturas. Quando fui secretário do jornal Opinião Pública, o Grêmio Esportivo Brasil, de Pelotas, fez uma excursão pelas Américas. Nós mandamos o repórter Ubirajara Timm, que acompanhou a excursão, fez a cobertura. Ele foi à Bolívia, Cochabamba, La Paz, Sucre, à Colômbia, à Venezuela, ao Panamá e ao México.

\section{Marli - Como material era enviado para o Brasil?}

Aldyr - Era uma coisa muito maluca. Não havia fax, nem teletipo. Da Bolívia foi possível fazer uma ligação telefônica para passar os resultados das partidas. Mas, havia um convênio com as companhias aéreas para se mandar o texto pronto. A primeira cobertura internacional que se fez aqui em Pelotas foi em 1950, mas eu ainda não morava aqui. Foi quando o Grêmio Esportivo Brasil foi jogar com a seleção uruguaia, em Montevidéu. Pelo telégrafo internacional se deu o resultado. Este, de Montevidéu foi ao Rio de Janeiro e de lá para Pelotas. Acho que era enviado via cabo. Depois, o texto vinha por via aérea, pela Varig, que fazia ligação Montevidéu-Jaquarão-Pelotas-Porto Alegre. O avião trazia já datilografado. O texto estava pronto para publicar.

Marli - Além de escrever o texto, o repórter aparecia nas fotografias que eram publicadas?

Aldyr - Sim, isso era fundamental. Se o repórter não aparecia na fotografia não se tinha credibilidade. A credibilidade era dupla. Para autenticar a fotografia, deveria aparecer o repórter. Aquilo dava credibilidade ao texto e autenticidade ao fato. O repórter assumia, assim, a responsabilidade sobre o seu trabalho sem precisar assinar.

Marli - O senhor desenhava os gols das partidas para serem publicadas nos jornais? Como se dava esse processo? Havia outros profissionais que faziam isso?

Aldyr - Durante cada partida, eu anotava os detalhes da jogada que culminava num gol. Fazia um rascunho do lance, anotando nome dos jogadores envolvidos, recursos utilizados, peculiaridades, contagem do tempo e posição deste ou daquele (quando necessário). Em casa ou no jornal, depois, com caneta Gelot ou pincel, usava tinta nanquim 
para os traços e aguada para o "colorido" do resto. No mais fazia bonecos no meu estilo platino, não havia ninguém no centro do país, O Esporte Ilustrado, principalmente, a Gazeta Esportiva, o Jornal dos Sports... apresentavam apenas "gráficos" ou "esquemas" dos gols.

\section{Marli - Foi o crescimento do fotojornalismo (esportivo) que acabou com os} desenhos nas páginas esportivas?

Aldyr - Como percebes, pela resposta anterior, os desenhos dos golos das partidas não chegaram a constituir no Brasil uma característica das coberturas futebolísticas. Além disso, o fotojornalismo esportivo custou a ter relevância nos jornalões tradicionais, que só mudaram de cara lentamente (excluindo, por exemplo, as fotos posadas dos dois times, a cada jogo; e deixando comodamente de fazer a documentação dos gols ocorridos). Só com o advento da cor, nos jornais, e a necessidade de criar um impacto visual na cabeça do leitor, o fotojornalismo ganhou força e produziu aqueles canhões com que se postam os fotógrafos atrás das goleiras. Mas, eu te pergunto: quantas fotos relevantes são produzidas e impressas a cada jogo? O que sobrou nas páginas esportivas, em matéria de ilustração, são os excelentes desenhos e caricaturas dos jogadores que vemos por aí.

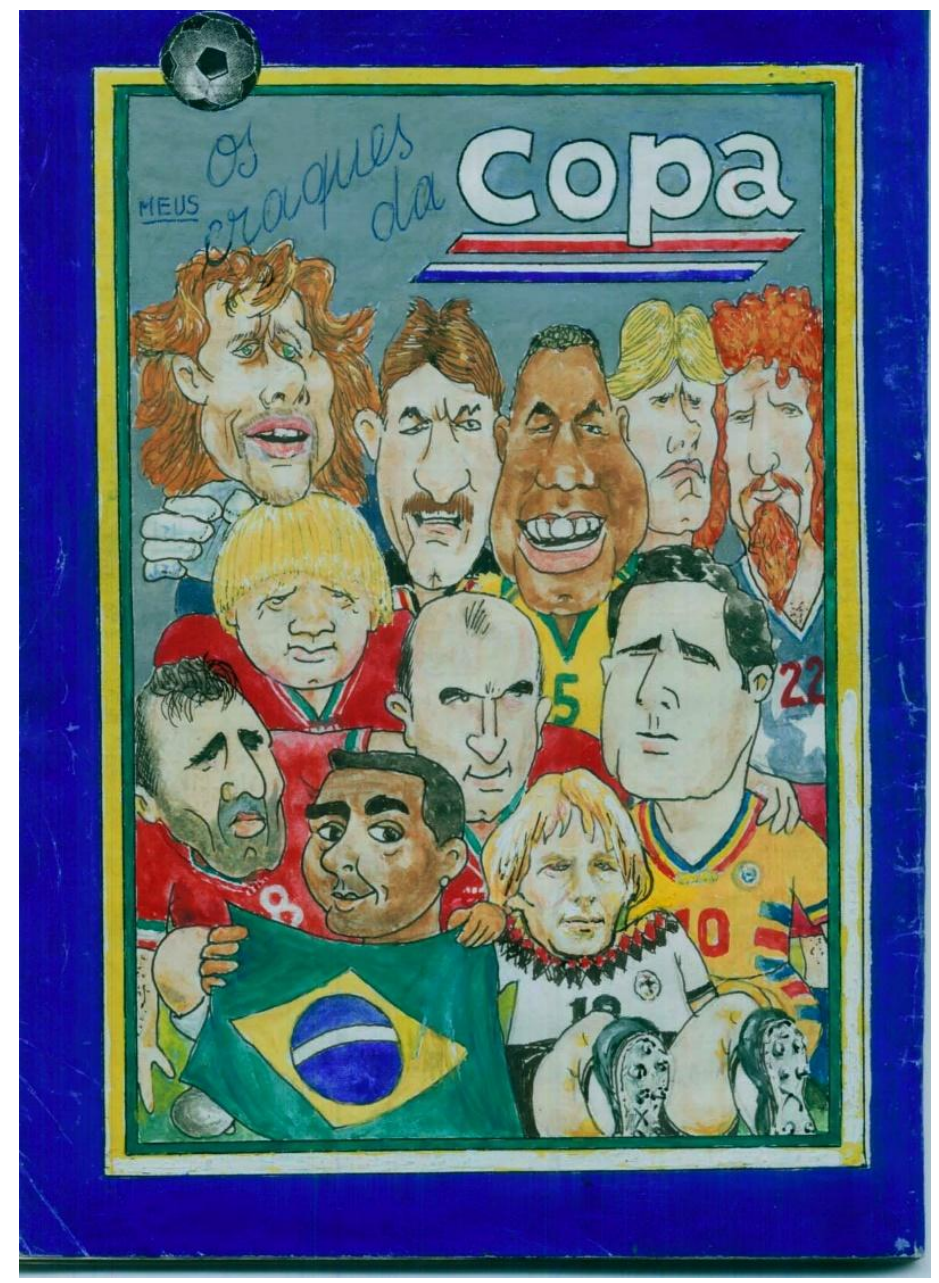

Figura 8 - Ilustração da Seleção Brasileira na Copa do Mundo de 1994. 


\section{Marli - As matérias não eram assinadas na época. Hoje são assinadas e o} repórter não aparece mais. Mudou alguma coisa com a transição?

Aldyr - Não havia matéria assinada. Eu dei aquele exemplo da coluna tríplice que criamos e na qual usávamos pseudônimo. Foi uma experiência, mas na verdade os textos não eram assinados. Hoje se põem as iniciais. Agora, a ilustração fotográfica passou por uma mudança que foi benéfica em termos de qualidade, de objetividade. Essa história de aparecer o repórter era tolice portuguesa, uma herança que trouxemos do jornalismo lusitano. Parece que em Portugal ainda é assim. Mas, por outro lado, perdeu-se algo, em detrimento da memória do esporte: acabou o "quadro da fotografia". O quadro, em que aparecia o time com os 11 jogadores. Antes do jogo eles posam e, nos jogos internacionais patrocinados pela FIFA é obrigatória essa foto: eles cantam o hino e vão lá, tanto times como seleções, e fazem a foto. Essa foto é fundamental para que se mantenha a memória esportiva. Mas, todos os jornais deixaram de publicá-la, inclusive, quando se tratava de um fato importante.

Quando o Grêmio ganhou um título de campeão gaúcho, no tempo em que Roger (atual treinador) jogava, a Zero Hora, anunciou que na edição de terça-feira publicaria um pôster com a equipe campeão. E sabe o que imprimiram? Uma coisa lamentável, uma tristeza. Por um descuido absurdo da editoria gráfica, da secretaria do jornal e, especialmente, da má qualificação do fotógrafo ou dos fotógrafos, eles publicaram uma foto de página dupla, central, do Grêmio. Mas, o repórter fotográfico não conseguiu enquadrar todos os 11 jogadores na imagem - e o Roger ficou fora do quadro. A foto é um horror, é a negação da fotografia tradicional de um time, cuja impressão se justificava pelo título conquistado. A foto que um sapateiro gostaria de guardar e colocar na parede de sua oficina ficou incompleta. E foi o que restou, na grande imprensa do Rio Grande do Sul, como testemunho capenga da obtenção de mais um campeonato pelo Grêmio de Porto Alegre.

Marli - É fundamental que a pessoa goste de esporte para atuar no jornalismo esportivo?

Adyr - É, é fundamental. Porque quem não gosta disto, tem que gostar daquilo. E, se gosta de futebol tem que ser um apaixonado pelo futebol ou então deve plantar batatas ou se preocupar com seu facebook.

Marli - E como jornalista esportivo o senhor era adepto à prática de atividade física? Continua hoje, ou apenas escrevias?

Adyr - Sim, sempre fui, mesmo sendo um perna de pau. Moro num sítio, no Capão do Leão, com campo de futebol, com cancha de vôlei, piscina e tudo. Nunca me desliguei dessas coisas. Meu segundo livro publicado em espanhol, chama-se "Cuentos de Fútbol". 


\section{Marli - Muito obrigada.}

\section{Outras informações sobre ALDYR GARCIA SCHLEE ${ }^{2}$}

Professor universitário, na área de ciências humanas, atuou desde 1960 na Universidade Católica de Pelotas (onde fundou o Curso de Jornalismo) e desde 1963 na Universidade Federal de Pelotas, onde foi Pró-Reitor, (de 1989 a 1992) e onde foi reconhecido como Professor Emérito.

Como jornalista, atuou inicialmente como ilustrador, diagramador e planejador gráfico; posteriormente como repórter, redator e secretário de redação, estando entre os vencedores do Prêmio Esso de Reportagem de 1963.

Como literato, na condição de professor visitante do Programa de Pós-Graduação em Letras da Pontifícia Universidade Católica do Rio Grande do Sul, esteve até 2003 naquela Universidade, inicialmente na condição de bolsista da CAPES e, depois, como pesquisador do CNPQ.

Foi Consultor Jurídico do Ministério das Relações Exteriores (1976-77) para a redação final do Tratado da Lagoa Mirim, firmado entre Brasil e Uruguai.

\section{PRÊMIOS}

Como escritor, foi vencedor da I Bienal de Literatura Brasileira, em 1982 (com CONTOS DE SEMPRE), da II Bienal, em 1984 (com UMA TERRA SÓ), e finalista do Prêmio Casa de las Américas, em Cuba (com LINHA DIVISÓRIA).

Ganhou o Prêmio Açorianos de Literatura seis vezes: em 1997, com a tradução de FACUNDO, de Domingo Faustino Sarmiento; em 1998, com CONTOS DE FUTEBOL; em 2001, com CONTOS DE VERDADES; em 2010, com OS LIMITES DO IMPOSSÍVEL; em 2011, com o romance DON FRUTOS; e em 2014, com CONTOS DA VIDA DIFÍCIL

Dois de seus livros (EL DÍA EN QUE EL PAPA FUE A MELO e CUENTOS DE FÚTBOL) foram editados inicialmente no Uruguai, na versão original, em espanhol.

\section{AUTOR DAS SEGUINTES OBRAS}

\section{Em português:}

- CONTOS DE SEMPRE (contos). São Paulo, LR Editores, 1983,

\footnotetext{
${ }^{2}$ Estas informações foram acrescentadas a entrevista original, pelo autor, em outubro de 2015, quando Aldyr Garcia Schlee revisou o texto da entrevista concedida em 1995.
} 
- UMA TERRA SÓ (contos), São Paulo: Melhoramentos, 1984.

- LINHA DIVISÓRIA (contos). São Paulo: Melhoramentos, 1988

- CONTOS DE FUTEBOL (contos). Porto Alegre: Mercado Aberto, 1997.

- O DIA EM QUE O PAPA FOI A MELO (contos). Porto Alegre: Mercado Aberto, 1999

- CONTOS DE VERDADES (contos). Porto Alegre: Mercado Aberto, 2000.

- EDIÇÃO CRÍTICA de Contos Gauchescos e Lendas do Sul, de J. Simões Lopes Neto. Porto Alegre. IEL/Ed. Unisinos (2 vols.) 2006..

- OS LIMITES DO IMPOSSÍ VEL (contos). Porto Alegre: Ardotempo, 2009.

- DON FRUTOS (romance). Porto Alegre, Ardotempo, 2010.

- LEMBRANÇA DE J.SIMÕES LOPES NETO (ensaio). Pelotas, Fructos do Paiz, 2010.

- OS CONTOS \& LENDAS DE J.SIMÕES LOPES NETO (edição revisada e comentada). Pelotas: Fructos do Paiz, 2010.

- O VOCABULÁRIO DE JOÃO SIMÕES LOPES NETO (pesquisa comentada). Pelotas: Fructos do Paiz, 2010.

- CONTOS DA VIDA DIFÍCIL (contos). Porto Alegre: Ardotempo, 2013.

- MEMÓRIAS DE O QUE JÁ NÃO SERÁ (contos). Porto Alegre: Ardotempo, 2014.

- OS 20 MELHORES CONTOS DE ALDYR GARCIA SCHLEE (contos). Porto Alegre: Ardotempo, 2014

- FITAS DE CINEMA (contos). Porto Alegre: Ardotempo, 2015.

Em espanhol:

- EL DÍA EN QUE EL PAPA FUE A MELO, Montevidéu, Uruguai, Ed. Banda Oriental, 1991 (contos) - várias edições.

- CUENTOS DE FÚTBOL, Montevidéu, Uruguai, Ed. Banda Oriental,1995 (contos) várias edições..

- AQUELLA TARDE IMPOSIBLE (conto) in ESCRITO EN EL CESPED (antología), Montevidéu, Uruguai, Ed. Banda Oriental, 1998.

Publicações em antologias

- A Falta de Tabaré (conto), in 22 CONTISTAS EM CAMPO (seleção de Flávio Moreira da Costa), Rio de Janeiro: Ediouro, 2006.

- Encanto de Futebol (conto) in CONTOS BRASILEIROS DE FUTEBOL, Ed. L.G.E, Brasília, 2005.

- O Barco das Ilusões (conto) in OS 35 MELHORES CONTOS DO RIO GRANDE DO SUL (organização de Maria da Glória Bordini), Porto Alegre: Corag / IEL, 2003. 
- Como uma Parábola (conto) in OS 35 MELHORES CONTOS DO RIO GRANDE DO SUL (organização de Maria da Glória Bordini), Porto Alegre: Corag / IEL, 2003.

- Maria Adélia (conto) in TRILHOS NA CABEÇA, Edizioni Dr. Antonino Sfameni, Messina (Itália), 2003.

- Maestros del Fútbol e Maria Adélia (contos) in MEIA ENCARNADA DURA DE SANGUE (organização de Ruy Carlos Osterman), Porto Alegre: Artes \& Ofícios, 2001.

- Noite de Natal (conto) in CINCO HISTÓRIAS DO SUL, Porto Alegre. Coleção Clássicos Populares - Unidade Editorial, Secretaria Municipal de Cultura, 2001.

- Braulina e Anão da Circo (contos) in PARA LER OS GAÚCHOS, Porto Alegre: Novo Século, 2000

- Conto IX (conto) in CONTOS SEM FRONTEIRAS, Porto Alegre, - Unidade Editorial, Secretaria Municipal de Cultura, 2000.

- A Viúva de Quinteros (conto) in O AUTOR PRESENTE - Literatura Gaúcha, Porto Alegre, IEL, 1997.

- Os Alemães (relato) in NÓS, OS TEUTO-GAÚCHOS, Porto Alegre: UFRGS, 1996.

- Que trama é esta do será, do é, do foi? (devaneio) in NÓS, OS GAÚCHOS II, Porto Alegre: UFGRS, 1994.

- Don Sejanes (conto traduzido) in CUENTOS BRASILEÑOS CONTEMPORANEOS, Havana, Cuba, Ed. Arte y Literatura, 1991.

- A Verdade e a Mentira sobre Hugo del Carril e o Grande Heleno de Freitas (conto) in FICÇÕES, Porto Alegre: Mercado Aberto, 1988.

- O Sinal (conto)in PAU BRASIL, São Paulo, DAAE, 1986

- Ida e Volta (conto) in RODÍZIO DE CONTOS, Porto Alegre: Mercado Aberto, 1985.

- Pan Viejo, Pláquete-pláquete e O Sulque de Rodas Vermelhas (contos) in HISTÓRIAS ORDINÁRIAS, Porto Alegre, Cooperativa de Escritores Gaúchos, 1977.

Traduções do espanhol:

- PARA SEMPRE URUGUAI (contos de 22 autores uruguaios) Trad. e org. com Sérgio Faraco, Porto Alegre, IEL, 1991.

- FACUNDO, de Domingo Faustino Sarmiento (tradução, estudo crítico e notas), Porto Alegre: UFGRS/PUCRS, 1996.

- PÁTRIA URUGUAIA, Eduardo Acevedo Díaz (tradução, seleção e notas). Porto Alegre, IEL, 1997.

- DON SEGUNDO SOMBRA, Ricardo Güiraldes (Edição anotada e comentada). Porto Alegre: Ardotempo, 2012. 


\section{Versões para o espanhol:}

- LA SAlAMANCA DEL JARAU, de João Simões Lopes Neto, Porto Alegre, IELIGEL,1991.

- CAMPO AFUERA, de Cyro Martins, Porto Alegre, IEL-CELP, 2000.

Original recebido em: 21/10/2015

Aceito para publicação em: 24/112015

\section{Marli Hatje}

Docente Associada IV do Centro de Educação Física e Desportos da Universidade Federal de Santa Maria. Coordenadora do Núcleo de Estudos e Pesquisas em Comunicação e Mídia na Educação Física e no Esporte (NEP-COMEFE). Líder de Grupo de Pesquisa no CNPq. E-mail: hatjehammes@yahoo.com.br

Esta obra está licenciada sob uma Licença Creative Commons 